\title{
Interactive effects of different inorganic As and Se species on their uptake and translocation by rice (Oryza sativa L.) seedlings
}

\author{
Ying Hu • Gui-Lan Duan • Yi-Zong Huang • \\ Yun-Xia Liu • Guo-Xin Sun
}

Received: 20 March 2013 /Accepted: 4 November 2013 / Published online: 3 December 2013

(C) Springer-Verlag Berlin Heidelberg 2013

\begin{abstract}
There is a lack of information on the interactive relationship of absorption and transformation between two inorganic arsenic (As) species and two inorganic selenium (Se) species in rice grown under hydroponic condition. Interactive effects of inorganic As (As(III)) and $(\mathrm{As}(\mathrm{V}))$ and $\mathrm{Se}$ (Se(IV)and $\mathrm{Se}(\mathrm{VI})$ ) species on their uptake, accumulation, and translocation in rice (Oryza sativa L.) seedlings were investigated in hydroponic culture. The results clearly showed the interactive effects of inorganic As and Se on their uptake by rice. The presence of Se reduced the sum of As species in the rice shoots regardless of $\mathrm{Se}$ speciation. If $\mathrm{Se}$ is present as $\mathrm{Se}(\mathrm{IV})$, then is it is accompanied by a corresponding increase of the sum of As species, but if Se is present as $\mathrm{Se}(\mathrm{VI})$, then there is no change in the sum of As species in rice roots. These effects are observed regardless of initial As speciation. When the rice plants are exposed to $\mathrm{Se}(\mathrm{IV})$, the presence of As increases the sum of Se species in the roots, and decreases the sum of Se species in the corresponding shoots. This effect is more pronounced for $\mathrm{As}(\mathrm{III})$ than for $\mathrm{As}(\mathrm{V})$. There is no effect on Se during exposure to $\mathrm{Se}(\mathrm{VI})$. Co-existence of As also increased SeMet in rice roots.
\end{abstract}

Keywords Arsenic $\cdot$ Selenium · Interactive effect $\cdot$ Rice . Speciation $\cdot$ Translocation

Responsible editor: Elena Maestri

Y. Hu • G.-L. Duan • Y.-Z. Huang • Y.-X. Liu • G.-X. Sun ( $\varangle)$ State Key Lab of Urban and Regional Ecology, Research Center for Eco-Environmental Sciences, Chinese Academy of Sciences, Beijing 100085, China

e-mail: gxsun@rcees.ac.cn

\section{Introduction}

Arsenic (As), as a kind of carcinogen, is ubiquitous in the environment, which pose the risk to human health for millions of people worldwide (Meharg 2004). In many countries, rice (Oryza sativa L.) was the major source of As intake because rice is the staple food for many populations ( $\mathrm{Li}$ et al. 2011; Rahman et al. 2008) and is a highly efficient As accumulator under anaerobic conditions in paddy soil. Selenium (Se) is an essential micronutrient and has important benefits for human within the appropriate content (Williams et al. 2009b). Cereals and cereal products such as rice are the main sources of dietary Se intake, so agronomic biofortification of food crops with $\mathrm{Se}$ fertilization is considered to be an effective way of improving Se intake for target populations (Hawkesford and Zhao 2007). However, the As contamination in paddy soil caused reduction of Se accumulation in rice grain (Williams et al. 2009a). Arsenic and Se are coupled in biogeochemical cycles (Couture et al. 2012) and in the way they appear in different geochemical strata (Edmonds and Francesconi 1987). As the ubiquitous elements, both inorganic As and Se co-exist in the rhizosphere soil. Therefore, interactive effects of As and Se would occur during uptake, assimilation, and transformation by/within plants. However, how As and Se affect uptake and translocation in plants with each other is still poorly understood.

In paddy soil, major As and Se are present as inorganic As, i.e., arsenite (As(III)) and arsenate ( $\mathrm{As}(\mathrm{V}))$ and inorganic Se, i.e., selenite $(\mathrm{Se}(\mathrm{IV}))$ and selenate $(\mathrm{Se}(\mathrm{VI}))$, although tiny amount of organic As or Se are existed as well due to the microbial transformation. Normally, As(III) dominates in anaerobic environment such as flooded paddy soils, but $\mathrm{As}(\mathrm{V})$ is the main species in aerobic soils (Abedin et al. 2002; Onken and Hossner 1996). Selenium species in paddy soil depend on 
the $\mathrm{pH}$. Selenite exists predominantly in well-drained mineral soils with $\mathrm{pH}$ from acidic to neutral $(7.5<\mathrm{pe}+\mathrm{pH}<15)$, like paddy soil, whereas $\mathrm{Se}(\mathrm{VI})$ is the predominant form in alkaline and well-oxidized soils ( $\mathrm{pe}+\mathrm{pH}>15$; Elrashidi et al. 1987). Plants take up As(V) through the phosphate transporters because of their chemical analog (Meharg and Hartley-Whitaker 2002; Meharg and Macnair 1992). Li et al. (2008) demonstrated that $\mathrm{Se}(\mathrm{IV})$ can also be taken up by the phosphate transporters. It seems reasonable to speculate that the uptake of $\mathrm{As}(\mathrm{V})$ and $\mathrm{Se}(\mathrm{IV})$ by plant roots presents competitive inhibition with each other. Arsenite is transported into rice by aquaporins (Meharg and Jardine 2003), such as silicon transporters (Ma et al. 2008). Interestingly, the uptake of $\mathrm{Se}(\mathrm{IV})$ is mediated by a silicon ( $\mathrm{Si}$ ) influx transporter Lsi1 in rice as well (Zhao et al. 2010). Therefore, competition between As(III) and Se(IV) uptake is likely present through silicon transporters. However, so far, no systematic investigation is available about the interactive relationship between inorganic As (As(III) and As(V)) and inorganic Se (Se(IV) and $\mathrm{Se}(\mathrm{VI})$ ) during uptake and translocation by/within plants.

Selenate as analog of sulfate is taken up by plants from the soil via sulfate transporters in the roots (Hawkesford and Zhao 2007). The content of sulhydryl groups containing sulfur might be reduced in the presence of Se due to the competetive uptake of Se and sulfate by plants (Zhu et al. 2009). This might affect As accumulation in plants because, in rice, As is particularly present as thiol complex in thiol-containing amino acids (Lombi et al. 2009). There is significant evidence that exposure to $\mathrm{As}(\mathrm{V})$ caused the generation of reactive oxygen species, phytochelatins production, glutathione depletion, and lipid peroxidation (Hartley-whitaker et al. 2001). In contrast, Se acted as an antioxidant, inhibiting lipid peroxidation (reduced by $26-42 \%$ in the fronds) via increased levels of thiols and glutathione (increased by $24 \%$ in the fronds). Se activates plant protective mechanisms as an antioxidant, thereby alleviating oxidative stress (Srivastava et al. 2009). The oxidative damage due to As in plant was mitigated with Se application, which could be related to their accumulation with each other.

Until recently, only a few reports about the interactive effects of As and Se on plant uptake and accumulation were available and most of them are focused on terrestrial plants, such as Chinese brake fern (Pteris vittata L.; Feng et al. 2009; Srivastava et al. 2009), mung bean (Phaseolus aureus Roxb.; Malik et al. 2012), barley (Hordeum vulgare; Ebbs and Weinstein 2001), and alfalfa (Khattak et al. 1991). In addition, most of the present studies were focused on interaction of single inorganic As or Se species, such as As(V) and Se(IV) (Feng et al. 2009), As(V) and Se(VI) (Srivastava et al. 2009; Ebbs and Weinstein 2001). There is a lack of systematic information on the interaction between two inorganic As species and two inorganic Se species in higher plant such as rice grown under anaerobic condition. In addition, all related previous researches did not investigated transformation of As and Se during uptake and accumulation, which is very important since the speciation of As and Se is crucial for evaluating As toxicity and Se nutrition in foods. The interaction between As and Se have not been systematically studied, therefore, in this study, we investigate the interactive effect of two inorganic As and Se species on their uptake and accumulation by rice plants grown in hydroponic solution.

\section{Materials and methods}

Rice seedling preparation and culture conditions

Rice (O. sativa L.) seeds were surface sterilized in $30 \% \mathrm{H}_{2} \mathrm{O}_{2}$ solution for $15 \mathrm{~min}$ and thoroughly washed with deionized water (Chen et al. 2008). The seeds were germinated in moist perlite. After 3 weeks, the seedlings were precultured in a $7 \mathrm{~L}$ plastic box with $1 / 3$ strength nutrient solution for 1 week, and then the uniform seedlings were selected and transferred to poly(vinyl chloride) (PVC) pots (one plant per pot) containing $500 \mathrm{~mL}$ full-strength nutrient solution. The composition of the nutrient solution was: $5 \mathrm{mM} \mathrm{NH}_{4} \mathrm{NO}_{3}, 2 \mathrm{mM} \mathrm{K}_{2} \mathrm{SO}_{4}, 4 \mathrm{mM}$ $\mathrm{CaCl}_{2}, 1.5 \mathrm{mM} \mathrm{MgSO}_{4} \cdot 7 \mathrm{H}_{2} \mathrm{O}, 1.3 \mathrm{mM} \mathrm{KH}_{2} \mathrm{PO}_{4}$, and $50 \mu \mathrm{M}$ $\mathrm{Fe}(\mathrm{II})$-EDTA, $10 \mu \mathrm{M} \mathrm{H}_{3} \mathrm{BO}_{4}, 1 \mu \mathrm{M} \mathrm{ZnSO}{ }_{4} \cdot 7 \mathrm{H}_{2} \mathrm{O}, 1 \mu \mathrm{M}$ $\mathrm{CuSO}_{4} \cdot 5 \mathrm{H}_{2} \mathrm{O}, 5 \mu \mathrm{M} \mathrm{MnSO}_{4} \cdot \mathrm{H}_{2} \mathrm{O}, 0.5 \mu \mathrm{M} \mathrm{Na} \mathrm{MoO}_{4}$. $2 \mathrm{H}_{2} \mathrm{O}$, and $0.2 \mu \mathrm{M} \mathrm{CoSO} \mathrm{C}_{4} \cdot 7 \mathrm{H}_{2} \mathrm{O}$. The $\mathrm{pH}$ of this solution was adjusted to 5.5 with $\mathrm{KOH}$ or $\mathrm{HCl}$. The nutrient solution was renewed twice every week. Plants were grown in a controlled-environment growth room at a 14-h light period (260-350 $\mu \mathrm{mol} \mathrm{m} \mathrm{m}^{-2} \mathrm{~s}^{-1}$ ). The temperature was regulated to $28{ }^{\circ} \mathrm{C}$ during the daytime and $20{ }^{\circ} \mathrm{C}$ at night and the relative humidity was maintained at $70 \%$.

\section{Arsenic and selenium treatments}

For all treatments, inorganic As and Se were the As(III) as $\mathrm{NaAsO}_{2}, \mathrm{As}(\mathrm{V})$ as $\mathrm{NaAsO}_{4} \cdot 12 \mathrm{H}_{2} \mathrm{O}$, $\mathrm{Se}(\mathrm{IV})$ as $\mathrm{Na}_{2} \mathrm{SeO}_{3}$, and $\mathrm{Se}(\mathrm{VI})$ as $\mathrm{Na}_{2} \mathrm{SeO}_{4}$. Four-week-old rice seedlings were planted in PVC pots (one plant per pot) containing $500 \mathrm{~mL}$ nutrient solution with eight treatments: T1, $1 \mu \mathrm{M}$ As(III); T2, $1 \mu \mathrm{M} \mathrm{As}(\mathrm{V})$; T3, $1 \mu \mathrm{M} \mathrm{Se}(\mathrm{IV})$; T4, $1 \mu \mathrm{M} \mathrm{Se}(\mathrm{VI})$; T5, $1 \mu \mathrm{M}$ As(III)+1 $\mu \mathrm{M} \mathrm{Se(IV);} \mathrm{T6,} 1 \mu \mathrm{M}$ As(III)+1 $\mu \mathrm{M} \mathrm{Se}(\mathrm{VI})$; T7, $1 \mu \mathrm{M} \mathrm{As}(\mathrm{V})+1 \mu \mathrm{M} \mathrm{Se}(\mathrm{IV})$; and $\mathrm{T} 8,1 \mu \mathrm{M} \mathrm{As}(\mathrm{V})+1 \mu \mathrm{M}$ $\mathrm{Se}(\mathrm{VI})$. Each treatment was replicated in four pots. The culture medium was replaced by newly prepared solution every $24 \mathrm{~h}$ to avoid the speciation changes of As or Se species in the culture medium during the experiments. Two kinds of control were included in the experiment, the medium control in which the medium added the same concentration of As, Se, or their mixture but without rice seedling, and the plant control in 
which the rice plants were grown in the same medium but without As or Se addition.

\section{Sample preparation}

After exposure to As, Se, or their mixture for $48 \mathrm{~h}$, the rice plants were harvested. Shoots and roots were separated; the shoots were rinsed with deionized water, blotted dry, and then frozen in liquid nitrogen. For seedlings with As treatments, the roots were rinsed and dipped in an ice-cold desorption solution containing $0.5 \mathrm{mM} \mathrm{Ca}\left(\mathrm{NO}_{3}\right)_{2}, 5 \mathrm{mM}$ MES ( $\mathrm{pH} 5.5$ ), and $1 \mathrm{mM} \mathrm{K}_{2} \mathrm{HPO}_{4}$ for $15 \mathrm{~min}$ to remove adhered As (Abedin et al. 2002). For Se treatments, the roots were rinsed and dipped in an ice-cold desorption solution containing $0.5 \mathrm{mM}$ $\mathrm{Ca}\left(\mathrm{NO}_{3}\right)_{2}, 5 \mathrm{mM}$ MES (pH 5.5), and $0.5 \mathrm{mM} \mathrm{K}_{2} \mathrm{SO}_{4}$ for 15 min to remove surface Se (Zhang et al. 2006). Roots were blotted dry and frozen in liquid nitrogen. Shoots and roots were ground in liquid nitrogen to fine powder with a mortar and pestle for As and Se sample preparation.

\section{Analysis for As speciation}

To analyze the As speciation in rice shoots and roots, $0.1 \mathrm{~g}$ finely ground shoot and root powder were weighed into a $50 \mathrm{~mL}$ volume centrifuge tube with the addition of $10 \mathrm{~mL} 1 \%$ purity $\mathrm{HNO}_{3}$. After standing overnight at room temperature, the samples were extracted in a microwave digester (Mars, Matthews Inc., USA). The extraction program was set as follows: $55^{\circ} \mathrm{C}$ for $10 \mathrm{~min}, 75^{\circ} \mathrm{C}$ for $10 \mathrm{~min}$, and $95{ }^{\circ} \mathrm{C}$ for 30 min with $5 \mathrm{~min}$ ramp time between each stage. A standard reference plant material (GBW07605 from the National Research Center for Standards in China) was included to verify the accuracy and precision of the extraction procedure and subsequent analysis. After extraction, the samples were centrifuged $(5,000 \mathrm{rpm})$ for $10 \mathrm{~min}$ and the supernatants were filtered through $0.45 \mu \mathrm{m}$ nitrocellulose filters (Sartorius, Goettingen, Germany) for analysis.

Arsenic speciation in shoot and root tissues was determined using high performance liquid chromatography (HPLC; Agilent Technologies 1100 series) coupled with inductively coupled plasma mass spectrometry (ICP-MS, 7500, Agilent Technologies) as described in published paper (Islam and Meharg 2008). Arsenic species, i.e., As(III), As(V), methylarsonic acid (MMA), and dimethylarsinic acid (DMA) were separated by a PRP-X100 anion-exchange column $(250 \times 4.1 \mathrm{~mm}, 10 \mu \mathrm{m}$; Hamilton, UK) with the mobile phase consisted of $10 \mathrm{mM}\left(\mathrm{NH}_{4}\right)_{2} \mathrm{HPO}_{4}$ and $10 \mathrm{mM}$ $\mathrm{NH}_{4} \mathrm{NO}_{3}$, adjusted to $\mathrm{pH} 6.2$ using $\mathrm{HNO}_{3}$ at flow rate $1 \mathrm{~mL} \cdot \mathrm{min}^{-1}$. Arsenic species were identified and quantified by comparing with the retention times of standard compounds and the external calibration curves with peak areas.
Measurements of sample extracts were carried out within $12 \mathrm{~h}$ after extraction.

Analysis for Se speciation

For Se speciation in rice shoots and roots, the sample preparation and analysis were conducted as published paper (Sun et al. 2010) with minor modification. Briefly finely ground materials $(0.1 \mathrm{~g})$ were weighed into a $50 \mathrm{~mL}$ centrifuge tube, and protease $\mathrm{K}(20 \mathrm{mg})$, lipase VII $(10 \mathrm{mg})$, and $5 \mathrm{~mL}$ of $30 \mathrm{mM}$ Tris- $\mathrm{HCl}$ buffer solution (pH 7.5) were added. After tubes were constantly and gently homogenized on a water bath rotary shaker $(60 \mathrm{rpm})$ at $37^{\circ} \mathrm{C}$ in dark for $24 \mathrm{~h}$, samples were centrifuged at $3,000 \mathrm{rpm}$ for $30 \mathrm{~min}$, and the supernatants were filtered through $0.45 \mu \mathrm{m}$ filters for analysis. The supernatants were kept at $-20{ }^{\circ} \mathrm{C}$ and measured within $24 \mathrm{~h}$ after preparation in order to minimize possible Se species changes during storage.

The Se species in the supernatants were determined by HPLC-ICP-MS (HPLC, Agilent Technologies 1100 series, ICP-MS, 7500, Agilent Technologies; Sun et al. 2010). Selenium species were separated by a precolumn and a Hamilton PRP X-100 anion exchange column $(250 \times 4.1 \mathrm{~mm}, 10 \mu \mathrm{m})$. The mobile phase was $5 \mathrm{mM}$ ammonium citrate with $\mathrm{pH} 4.3$ containing $2 \%$ of methanol with a flow rate at $1 \mathrm{~mL} \mathrm{~min}^{-1}$. Mix comprising standards of $50 \mu \mathrm{g} \mathrm{L}^{-1}$ selenocystine (SeCys), Se-methyl-selenocysteine (MeSeCys), Se(IV), selenometnionine (SeMet), and Se(VI) were used to identify Se species by the retention times, and the quantities of $\mathrm{Se}$ species were calculated by the external calibration curves with peak areas measurements.

Statistical analysis

Data analysis was completed by SPSS software. One-way analysis of variance, which is based on the same assumptions as the $t$ test, was used to identify significant differences $(P<$ $0.05)$ between As or Se species concentration in rice shoots and roots by comparing different treatments such as As(III), $\mathrm{As}(\mathrm{III})+\mathrm{Se}(\mathrm{IV})$, and $\mathrm{As}(\mathrm{III})+\mathrm{Se}(\mathrm{VI})$.

\section{Results}

Measurement of As and Se in control samples

No changes in As or Se species were observed in the blanks without rice seedlings during the experiment $(24 \mathrm{~h})$, indicating that inorganic As and $\mathrm{Se}$ are stable in the culture medium within $24 \mathrm{~h}$ (data not shown). No As or Se species were 
measurable in the rice tissues which were not exposed to As and/or Se (data not shown).

Inorganic Se suppressed the transfer of inorganic As from rice root to shoot

Both addition of Se(IV) and Se(VI) significantly $(P<0.05)$ decreased As(III), As(V) and the sum of As species concentration in rice shoots (Fig. 1). Comparing with As(III) exposure alone, $\mathrm{Se}(\mathrm{IV})$ addition decreased the concentrations of $\mathrm{As}(\mathrm{III}), \mathrm{As}(\mathrm{V})$, and the sum of As species in rice shoots by $61.0,44.2$, and $59.0 \%$ respectively. The addition of $\mathrm{Se}(\mathrm{VI})$ decreased $\mathrm{As}(\mathrm{III}), \mathrm{As}(\mathrm{V})$ and the sum of As species levels of rice shoots by 33.2, 39.5, and $34.0 \%$ respectively. As for $\mathrm{As}(\mathrm{V})$ treatments, the concentrations of $\mathrm{As}(\mathrm{III}), \mathrm{As}(\mathrm{V})$, and the sum of As species were 48.3, 42.9, and $46.8 \%$ lower in $\mathrm{As}(\mathrm{V})+\mathrm{Se}(\mathrm{IV})$ treatment, respectively, and 51.7, 61.9, and $54.4 \%$ lower in $\mathrm{As}(\mathrm{V})+\mathrm{Se}(\mathrm{VI})$ treatment respectively, than that in $\mathrm{As}(\mathrm{V})$ treatment alone. These results indicated that inorganic Se significantly decreased the transfer of inorganic As from root to shoot.

Selenite increased As accumulation in rice root

The supply of Se(IV) significantly $(P<0.05)$ increased As accumulation in roots comparing with $\mathrm{As}(\mathrm{III})$ or $\mathrm{As}(\mathrm{V})$ addition alone, respectively (Fig. 1), while no significant effects on As uptake and accumulation in roots were observed by supplying $\mathrm{Se}(\mathrm{VI})$. The concentrations of $\mathrm{As}(\mathrm{III}), \mathrm{As}(\mathrm{V})$ and sum

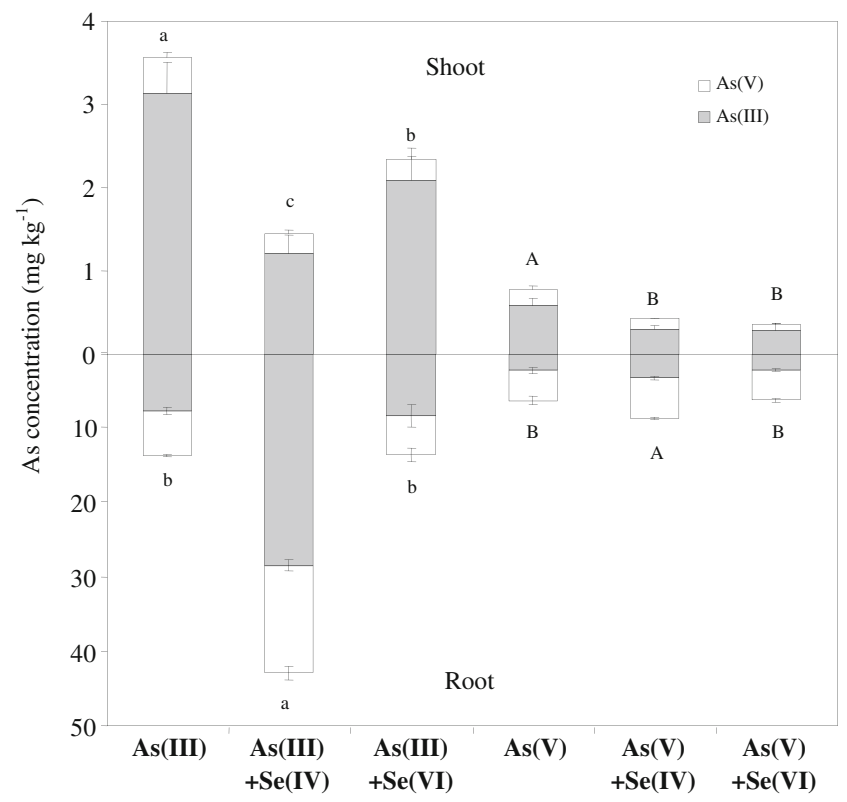

Fig. 1 Effect of inorganic Se on uptake of $\mathrm{As}(\mathrm{III})$ and $\mathrm{As}(\mathrm{V})$ by rice roots and shoots. Different letters above the bars in the same As species treatment indicate a significant difference at $P<0.05, n=4$. Samples were prepared and analyzed by HPLC-ICP-MS as described in "Materials and methods" section. Concentrations are from fresh weight of As species in $\mathrm{As}(\mathrm{III})+\mathrm{Se}(\mathrm{IV})$ treated roots were 3.7, 2.4, and 3.1 times, respectively, of those in As(III)-treated roots, and in $\mathrm{As}(\mathrm{V})+\mathrm{Se}(\mathrm{IV})$-treated roots, which were $1.4,1.3$, and 1.4 times, respectively, of those in $\mathrm{As}(\mathrm{V})$-treated roots.

Se addition changed inorganic As distribution in rice roots and shoots

In all As-containing treatments, As presented as inorganic As species, while organic As, like MMA and DMA, were not detected in either rice shoots or roots. the percentages of As(III) to the sum of As species (70.8-88.6\%) were much higher than that of $\mathrm{As}(\mathrm{V})(11.4-29.2 \%)$ in rice shoots, suggesting As(III) was the predominant As species in rice shoot (Table 1). A similar trend was observed by Meng et al. (2011), who reported that As(III) accounted for $90 \%$ in the shoots in both transgenic and wild type rice treated with $10 \mu \mathrm{M}$ As(III) for 4 weeks. In As(III)-treated plants, supplying Se(IV) significantly $(P<0.05)$ increased the percentage of As(III) in roots $(68.6 \%)$, thereby decreased percentage of $\mathrm{As}(\mathrm{V})$ in roots, whereas no significant differences were found in other treatments $(\mathrm{As}(\mathrm{III})+\mathrm{Se}(\mathrm{IV}), \mathrm{As}(\mathrm{V})+\mathrm{Se}(\mathrm{IV})$, and $\mathrm{As}(\mathrm{V})+$ $\mathrm{Se}(\mathrm{VI}))$ both in shoots and roots. Both addition of Se(IV) and $\mathrm{Se}(\mathrm{VI})$ significantly $(P<0.05)$ decreased the shoot-toroot $\mathrm{As}(\mathrm{III})$ and $\mathrm{As}(\mathrm{V})$ concentration ratio compared with $\mathrm{As}(\mathrm{III})$ or $\mathrm{As}(\mathrm{V})$ treatment alone, and the effect of Se(IV) supply on the shoot-to-root As concentration ratio was more significant than that of Se(VI) supply in the As(III)-treated plant (Table 1).

Effects of $\mathrm{As}(\mathrm{III})$ and $\mathrm{As}(\mathrm{V})$ on Se uptake, accumulation, and transfer by/within rice seedlings

Addition of As(III) or As(V) increased sum of Se species accumulation in rice roots in the presence of Se(IV) but no significant effect on its uptake and accumulation in the presence of $\mathrm{Se}(\mathrm{VI})$ (Table 2), causing the sum of Se species in the Se(IV) treatments was much higher ( $>10$ times) than that in the Se(VI) treatments (Table 2). In the rice shoots, the sum of Se species concentration $\left(2.2-4.7 \mathrm{mg} \mathrm{kg}^{-1}\right)$ in different $\mathrm{Se}$ (IV) treatments were much lower than that in their corresponding roots (15.32-25.90 mg kg${ }^{-1}$ ), while in different $\mathrm{Se}(\mathrm{VI})$ treatments, the sum of Se species concentrations in shoots (1.62$1.67 \mathrm{mg} \mathrm{kg}^{-1}$ ) were similar to that in corresponding roots (1.20-1.43 $\mathrm{mg} \mathrm{kg}^{-1}$; Table 2). In all Se(IV)-treated rice, the shoot-to-root sum of Se species ratio ranged between 0.08 and 0.31 , but in all $\mathrm{Se}(\mathrm{VI})$-treated plant, ranged between 1.14 and 1.35 , indicating that most of Se remained in roots of plants exposed to Se(IV). In contrast, more percentage of Se was transported to shoots of plant treated with $\mathrm{Se}(\mathrm{VI})$. The results suggested that As suppressed Se transfer from root to shoot after exposure to $\mathrm{Se}(\mathrm{IV})$, but not $\mathrm{Se}(\mathrm{VI})$. 
Table 1 Percentage of As(III) and As(V) in shoots and roots, and shoot to root As ratio. Different letters in column within the same As species treatment indicate a significant difference at $P<0.05, n=4$

\begin{tabular}{|c|c|c|c|c|c|c|}
\hline \multirow[t]{2}{*}{ Treatments } & \multicolumn{2}{|l|}{ Shoot $(\%)$} & \multicolumn{2}{|l|}{ Root $(\%)$} & \multicolumn{2}{|c|}{ Shoot to root As concentration ratio } \\
\hline & As(III) & $\mathrm{As}(\mathrm{V})$ & As(III) & $\mathrm{As}(\mathrm{V})$ & $\mathrm{As}(\mathrm{III})$ & $\mathrm{As}(\mathrm{V})$ \\
\hline $\mathrm{As}(\mathrm{III})$ & $87.6 \pm 1.82 \mathrm{a}$ & $12.4 \pm 1.82 \mathrm{a}$ & $56.2 \pm 2.14 \mathrm{a}$ & $43.8 \pm 2.14 \mathrm{a}$ & $0.461 \pm 0.01 \mathrm{a}$ & $0.082 \pm 0.01 \mathrm{a}$ \\
\hline $\mathrm{As}(\mathrm{III})+\mathrm{Se}(\mathrm{IV})$ & $87.0 \pm 1.40 \mathrm{a}$ & $13.0 \pm 1.40 \mathrm{a}$ & $68.6 \pm 2.30 \mathrm{~b}$ & $31.4 \pm 2.30 \mathrm{~b}$ & $0.041 \pm 0.01 \mathrm{c}$ & $0.017 \pm 0.00 \mathrm{c}$ \\
\hline $\mathrm{As}(\mathrm{III})+\mathrm{Se}(\mathrm{VI})$ & $88.6 \pm 1.05 \mathrm{a}$ & $11.4 \pm 1.05 \mathrm{a}$ & $62.3 \pm 2.39 \mathrm{ab}$ & $37.7 \pm 2.39 \mathrm{ab}$ & $0.226 \pm 0.01 \mathrm{~b}$ & $0.048 \pm 0.00 \mathrm{~b}$ \\
\hline $\mathrm{As}(\mathrm{V})$ & $76.1 \pm 2.84 \mathrm{~A}$ & $23.9 \pm 2.84 \mathrm{~A}$ & $36.1 \pm 1.53 \mathrm{~A}$ & $63.9 \pm 1.53 \mathrm{~A}$ & $0.286 \pm 0.03 \mathrm{~A}$ & $0.051 \pm 0.00 \mathrm{~A}$ \\
\hline $\operatorname{As}(\mathrm{V})+\mathrm{Se}(\mathrm{IV})$ & $70.8 \pm 2.01 \mathrm{~A}$ & $29.2 \pm 2.01 \mathrm{~A}$ & $38.1 \pm 1.67 \mathrm{~A}$ & $61.9 \pm 1.67 \mathrm{~A}$ & $0.090 \pm 0.01 \mathrm{~B}$ & $0.022 \pm 0.00 \mathrm{~B}$ \\
\hline $\mathrm{As}(\mathrm{V})+\mathrm{Se}(\mathrm{VI})$ & $74.6 \pm 4.12 \mathrm{~A}$ & $25.4 \pm 4.12 \mathrm{~A}$ & $37.0 \pm 2.39 \mathrm{~A}$ & $63.0 \pm 2.39 \mathrm{~A}$ & $0.119 \pm 0.03 \mathrm{~B}$ & $0.021 \pm 0.00 \mathrm{~B}$ \\
\hline
\end{tabular}

Effects of $\mathrm{As}(\mathrm{III})$ and $\mathrm{As}(\mathrm{V})$ on Se species in rice roots and shoots

In all $\mathrm{Se}(\mathrm{IV})$-treated roots, apart from $\mathrm{SeCys}, \mathrm{MeSeCys,}$ $\mathrm{Se}(\mathrm{IV})$, and SeMet, there were two kinds of unidentified Se compounds (named unknown 1 and 2), which were not observed in shoots (Table 2). In Se(IV)-treated roots, supply of As(III) significantly $(P<0.05)$ increased the concentration of SeMet and unknown 1 in roots by 1.5 - and 2.0 -fold, resulting in the increase of sum of Se species by 1.7 times compared with Se(IV) treatment alone. Similar to As(III), supply of As $(\mathrm{V})$ significantly $(P<0.05)$ increased SeMet concentration by 1.6-fold compared with $\mathrm{Se}(\mathrm{IV})$ treatment alone. In $\mathrm{Se}(\mathrm{VI})$ treated roots, only SeCys, SeMet, and $\mathrm{Se}(\mathrm{VI})$ were tested and $\mathrm{Se}(\mathrm{VI})$ was the predominant Se species, accounting for $53.1 \%$ in $\mathrm{Se}(\mathrm{VI})+\mathrm{As}(\mathrm{V})$ treatment, $54.2 \%$ in $\mathrm{Se}(\mathrm{VI})$ treatment and $60.6 \%$ in $\mathrm{Se}(\mathrm{VI})+\mathrm{As}(\mathrm{III})$ treatment (Table 2). These results indicated that organic Se predominated in Se(IV)-treated roots (accounted for 87.9-92.2\%), while inorganic Se (Se(VI)) (accounted for 53.1-60.6\%) predominated in $\mathrm{Se}(\mathrm{VI})$-treated roots.

The supply of $\mathrm{As}(\mathrm{III})$ and $\mathrm{As}(\mathrm{V})$ significantly $(P<0.05)$ decreased the shoot-to-root SeMet concentration ratio by 92.5 and $85.8 \%$, respectively, compared with Se(IV) treatment alone. In all Se(IV)-treated shoots, the effect of As(III) supply on SeMet concentration was more significant $(P<0.05)$ than that of $\mathrm{As}(\mathrm{V})$. The concentrations of SeMet were decreased by $58.6 \%$ by supplying $\mathrm{As}(\mathrm{III})$ and $17.5 \%$ by supplying $\mathrm{As}(\mathrm{V})$, respectively, compared with Se(IV)-treated shoots (Table 2). The percentage of Se species in the sum of Se species of whole plant indicated that $\mathrm{Se}(\mathrm{VI})$ is easier to be translocated from root to shoot, while Se(IV) could not be transferred from root to shoot (Table 3). More SeMet existed in the shoots than roots, suggesting that SeMet is easily transferred from roots to shoots as well. The co-exposure of As with Se(IV) suppressed the SeMet transfer in comparison with Se(IV) treatment alone.

Table 2 Effects of As(III) and As(V) on uptake and assimilation of selenium species in rice roots and shoots (in milligram per kilogram FW)

\begin{tabular}{|c|c|c|c|c|c|c|c|c|c|}
\hline & Treatments & SeCys & MeSeCys & $\mathrm{Se}(\mathrm{IV})$ & SeMet & Unknow 1 & Unknow 2 & $\mathrm{Se}(\mathrm{VI})$ & Sum Se \\
\hline \multirow[t]{6}{*}{ Shoots } & $\mathrm{Se}(\mathrm{IV})$ & $0.32 \pm 0.09 \mathrm{a}$ & $0.24 \pm 0.03 \mathrm{a}$ & ND & $4.18 \pm 0.27 \mathrm{a}$ & ND & ND & ND & $4.74 \mathrm{a}$ \\
\hline & $\mathrm{Se}(\mathrm{IV})+\mathrm{As}(\mathrm{III})$ & $0.23 \pm 0.02 \mathrm{~b}$ & $0.22 \pm 0.04 \mathrm{a}$ & ND & $1.73 \pm 0.11 b$ & ND & ND & ND & $2.18 \mathrm{~b}$ \\
\hline & $\mathrm{Se}(\mathrm{IV})+\mathrm{As}(\mathrm{V})$ & $0.18 \pm 0.01 \mathrm{c}$ & $0.18 \pm 0.02 \mathrm{a}$ & ND & $3.45 \pm 0.31 \mathrm{c}$ & ND & ND & ND & $3.81 \mathrm{a}$ \\
\hline & $\mathrm{Se}(\mathrm{VI})$ & $0.09 \pm 0.01 \mathrm{~A}$ & ND & ND & $0.38 \pm 0.03 \mathrm{~A}$ & ND & ND & $1.15 \pm 0.13 \mathrm{~A}$ & $1.62 \mathrm{~A}$ \\
\hline & $\mathrm{Se}(\mathrm{VI})+\mathrm{As}(\mathrm{III})$ & $0.08 \pm 0.01 \mathrm{~A}$ & ND & ND & $0.28 \pm 0.04 \mathrm{~B}$ & ND & ND & $1.27 \pm 0.10 \mathrm{~A}$ & $1.63 \mathrm{~A}$ \\
\hline & $\mathrm{Se}(\mathrm{VI})+\mathrm{As}(\mathrm{V})$ & $0.07 \pm 0.01 \mathrm{~A}$ & ND & ND & $0.43 \pm 0.05 \mathrm{~A}$ & ND & ND & $1.17 \pm 0.02 \mathrm{~A}$ & $1.67 \mathrm{~A}$ \\
\hline \multirow[t]{6}{*}{ Roots } & $\mathrm{Se}(\mathrm{IV})$ & $1.70 \pm 0.53 \mathrm{a}$ & $2.33 \pm 0.38 \mathrm{a}$ & $1.85 \pm 0.19 \mathrm{a}$ & $3.88 \pm 1.83 \mathrm{a}$ & $2.95 \pm 0.53 \mathrm{a}$ & $2.61 \pm 0.26 \mathrm{a}$ & ND & $15.32 \mathrm{a}$ \\
\hline & $\mathrm{Se}(\mathrm{IV})+\mathrm{As}(\mathrm{III})$ & $1.33 \pm 0.28 \mathrm{a}$ & $1.66 \pm 0.22 \mathrm{a}$ & $2.03 \pm 0.08 \mathrm{a}$ & $9.62 \pm 0.82 b$ & $8.98 \pm 1.16 b$ & $2.27 \pm 0.45 \mathrm{a}$ & ND & $25.90 \mathrm{~b}$ \\
\hline & $\mathrm{Se}(\mathrm{IV})+\mathrm{As}(\mathrm{V})$ & $1.88 \pm 0.32 \mathrm{a}$ & $2.09 \pm 0.22 \mathrm{a}$ & $1.51 \pm 0.28 \mathrm{a}$ & $10.02 \pm 0.24 \mathrm{~b}$ & $2.68 \pm 0.04 \mathrm{a}$ & $1.59 \pm 0.32 \mathrm{a}$ & ND & $19.77 \mathrm{a}$ \\
\hline & $\mathrm{Se}(\mathrm{VI})$ & $0.20 \pm 0.01 \mathrm{~A}$ & ND & ND & $0.35 \pm 0.03 \mathrm{~A}$ & ND & ND & $0.65 \pm 0.12 \mathrm{~A}$ & $1.20 \mathrm{~A}$ \\
\hline & $\mathrm{Se}(\mathrm{VI})+\mathrm{As}(\mathrm{III})$ & $0.21 \pm 0.02 \mathrm{~A}$ & ND & ND & $0.35 \pm 0.03 \mathrm{~A}$ & ND & ND & $0.87 \pm 0.06 \mathrm{~A}$ & $1.43 \mathrm{~A}$ \\
\hline & $\mathrm{Se}(\mathrm{VI})+\mathrm{As}(\mathrm{V})$ & $0.18 \pm 0.01 \mathrm{~A}$ & ND & ND & $0.41 \pm 0.01 \mathrm{~A}$ & ND & ND & $0.67 \pm 0.12 \mathrm{~A}$ & $1.26 \mathrm{~A}$ \\
\hline
\end{tabular}

Mean values \pm SE. Different letters in column within the same Se species treatment indicate a significant difference at $P<0.05, n=4$

$F W$ fresh weight, $N D$ not detected 
Table 3 The percentage of Se species in the sum Se of roots and shoots

\begin{tabular}{lllllllll}
\hline & $\%$ & SeCys & MeSeCys & SeMet & Se(VI) & Se(IV) & Unknow 1 & Unknow 2 \\
\hline \multirow{2}{*}{ Shoots } & Se(IV) & 3.92 & 3.12 & 53.31 & - & - & - & - \\
& $\mathrm{Se}(\mathrm{IV})+\mathrm{As}(\mathrm{III})$ & 2.75 & 2.57 & 18.34 & - & - & - & - \\
& $\mathrm{Se}(\mathrm{IV})+\mathrm{As}(\mathrm{V})$ & 2.18 & 2.21 & 42.33 & - & - & - & - \\
& $\mathrm{Se}(\mathrm{VI})$ & 5.19 & - & 21.62 & 60.29 & - & - & - \\
& $\mathrm{Se}(\mathrm{VI})+\mathrm{As}(\mathrm{III})$ & 4.59 & - & 15.85 & 62.56 & - & - & - \\
& $\mathrm{Se}(\mathrm{VI})+\mathrm{As}(\mathrm{V})$ & 4.11 & - & 21.84 & 61.89 & - & - & - \\
\multirow{5}{*}{ Roots } & $\mathrm{Se}(\mathrm{IV})$ & 4.50 & 6.28 & 6.36 & - & 5.38 & 9.48 & 7.65 \\
& $\mathrm{Se}(\mathrm{IV})+\mathrm{As}(\mathrm{III})$ & 3.43 & 4.19 & 25.35 & - & 4.55 & 33.74 & 5.10 \\
& $\mathrm{Se}(\mathrm{IV})+\mathrm{As}(\mathrm{V})$ & 5.44 & 5.33 & 27.22 & - & 4.07 & 7.24 & 3.99 \\
& $\mathrm{Se}(\mathrm{VI})$ & 2.14 & - & 3.81 & 6.95 & - & - & - \\
& $\mathrm{Se}(\mathrm{VI})+\mathrm{As}(\mathrm{III})$ & 2.38 & - & 4.00 & 10.62 & - & - & - \\
& $\mathrm{Se}(\mathrm{VI})+\mathrm{As}(\mathrm{V})$ & 1.71 & - & 3.92 & 6.53 & - & - & - \\
\hline
\end{tabular}

\section{Discussion}

The uptake of As or Se by rice root

Our results using co-exposure of different inorganic As and Se clearly show that inorganic As together with Se(IV), but not $\mathrm{Se}(\mathrm{VI})$, could improve uptake in rice root with each other (Fig. 1, Table 2). This conclusion is partly supported by other researcher (Feng et al. 2009), who reported that Se(IV) addition less than $2.5 \mathrm{mg} \cdot \mathrm{L}^{-1}$ stimulated $\mathrm{As}(\mathrm{V})$ uptake in roots of As hyperaccumulator $P$. vittata L. To the best of our knowledge, it is the first systematic investigation of As and Se interactive relationship and the observation that $\mathrm{Se}(\mathrm{IV})$ and inorganic As (As(III) or As(V)) improved uptake in rice root with each other. In addition, Se(IV) have stronger interaction with $\mathrm{As}(\mathrm{III})$ than $\mathrm{As}(\mathrm{V})$ because the sum of As species in roots from $\mathrm{As}(\mathrm{III})+\mathrm{Se}(\mathrm{IV})$ treatment is 3.1 times of that from $\mathrm{As}(\mathrm{III})$ treatment, higher than $\mathrm{As}(\mathrm{V})+\mathrm{Se}(\mathrm{IV})$ treatment (1.4 times) comparing with its corresponding control (As(V) treatment) (Fig. 1), moreover, Se(IV) accumulation enhanced by 1.7 times by $\mathrm{As}(\mathrm{III})$ addition, higher than that by $\mathrm{As}(\mathrm{V})$ addition (1.3 times; Table 2).

It is generally accepted that the As(III) influx in rice root through silicon influx transporters OsNIP2;1 (Ma et al. 2008). Zhao et al. (2010) clearly showed that this transporter is permeable to $\mathrm{Se}(\mathrm{IV})$. It seemed that antagonistic interaction between $\mathrm{As}$ (III) and Se(IV) would exist because they share the same transporter ( $\mathrm{Si}$ transporter). However, improvement rather than antagonism were observed for the uptake into root. The antagonistic interaction between $\mathrm{As}$ (III) and Se(IV) in rice was not observed by Zhao et al. (2010) either. The exact mechanisms on these are still unknown. Selenite as a diprotic weak acid is deprotonated in the environment with $\mathrm{pH}$ at 5.5 (culture medium utilized), and charged as $\mathrm{HSeO}_{3}{ }^{-}$(93\%) and $\mathrm{SeO}_{3}{ }^{2-}$ (7\%; Zhao et al. 2010). However, As(III) is uncharged molecules of arsenous acid $\left(\mathrm{As}(\mathrm{OH})_{3}\right)$ at $\mathrm{pH}<8$ (Ma et al. 2008). Silicon influx transporters belonging to aquaporins are permeable to uncharged substrates such as silicic acid, arsenite, and glycerol (Zhao et al. 2010). It was reasonable that As(III) but not Se(IV) was permeable through Si influx transporters at $\mathrm{pH}$ 5.5. Some studies demonstrated that $\mathrm{Se}(\mathrm{IV})$ uptake is at least partly to be mediated by phosphate transporters based on evidence that phosphorus deficiency enhanced Se(IV) uptake in wheat (Li et al. 2008) or increasing phosphate levels decreased Se(IV) uptake in different plant species (Hopper and Parker 1999). Whereas As(V) is taken up through phosphate transporters because of its chemical analog of phosphate (Wu et al. 2011). Antagonistic interaction between $\mathrm{As}(\mathrm{V})$ and $\mathrm{Se}(\mathrm{IV})$ would be observed due to the share of phosphate transporters. However, the results herein showed that improvement, not antagonism between Se(IV) and As(III) or $\mathrm{As}(\mathrm{V})$ during uptake by rice roots. It will be interesting to investigate the possible mechanism in the future. As for $\mathrm{Se}(\mathrm{VI})$, which is indicated to be taken up into plants via the sulfate transporter as the chemical analog of sulfate ion (Terry et al. 2000; Zhu et al. 2009), no strong effects on As transport or As uptake by Se(VI) was obtained and vice versa (Fig. 1, Table 2).

The translocation of As or Se from rice root to shoot

Selenium, regardless of Se(IV) or Se(VI), supplying significantly $(P<0.05)$ decreased As in rice shoots compared with the $\mathrm{As}(\mathrm{III})$ or $\mathrm{As}(\mathrm{V})$ treatment alone. This result indicated that the supply of inorganic Se, significantly decrease the translocation of As from roots to shoots (Table 1) and plays an antagonistic role in As translocation from roots to shoots. These findings are supported by other investigations in terrestrial plants. Malik et al. (2012) reported that the As-treated (10 $\mu \mathrm{M})$ mung bean supplemented with $5 \mu \mathrm{M}$ Se significantly reduced the As uptake by mung bean. Khattak et al. (1991) showed that Se strongly depressed shoot As concentration in alfalfa and Feng et al. (2009) observed Se application $\left(>2.5 \mathrm{mg} \mathrm{l}^{-1}\right)$ inhibited the transfer of As from the roots to 
fronds in Chinese brake fern as well. Our result clearly demonstrated that supplying inorganic Se depress the As translocation in flooded plants. An efflux transporter, Lsi2, has been demonstrated to be responsible for the efflux of As(III) toward the xylem (Ma et al. 2008). No efflux transporter were identified for Se (Zhu et al. 2009), and Lsi2 has been demonstrated to be not involved in the Se transport (Zhao et al. 2010). Therefore, the antagonistic interaction observed between As and Se might not occur at the efflux transporter Lsi2. One possible explanation is that the supply of inorganic Se elevated the synthesis of As ligands (e.g., phytochelatins, GSH) in roots (Malik et al. 2012) which sequestrate As into vacuoles of roots.

The presence of As repress the Se(IV) translocation from root to shoot, but not $\mathrm{Se}(\mathrm{VI})$ (Table 2). The translocation of Se from root to shoot is dependent on the form of Se supplied. $\mathrm{Se}(\mathrm{VI})$ is transported much more easily than $\mathrm{Se}(\mathrm{IV})$ or organic Se (Terry et al. 2000; Zhu et al. 2009). Selenite is mostly assimilated in the roots, and rapidly converted to organic forms of Se and retained in the roots (Zayed et al. 1998; Zhu et al. 2009). In this study, the possible reason for As suppressing Se(IV) translocation is suppression of SeMet translocation from the roots to shoots in As+Se(IV) treatment compared with $\mathrm{Se}(\mathrm{VI})$ treatment (Table 3).

The exact mechanism for interactive relationship of As and Se in uptake and translocation in plants is still unclear. To the best of our knowledge, this is the first report about interactive relationship of inorganic As and Se on uptake, translocation by wetland plants. Herein, all results suggested the presence of inorganic Se decrease the As translocation from rice root to shoot, and probable decrease the As levels in edible part (grain), which would decrease the human health risk of As from rice consumption. The presence of inorganic As reduced the translocation of Se(IV), which is predominant Se species in paddy soil. This would cause the loss of nutrient elements in rice grain, which is supported by the fact that grain Se levels were exhibited a highly decline with increasing As content in paddy soil (Williams et al. 2009a). In the future, further investigation in paddy field would be performed for both mitigating As contamination and improving Se nutrition in rice grains.

Acknowledgments This work was financially supported by Natural Science Foundation of China (nos. 41371459 and 21077100)

\section{References}

Abedin MJ, Feldmann J, Meharg AA (2002) Uptake kinetics of arsenic species in rice plants. Plant Physiol 1(128):1120-1128

Chen XP, Kong WD, He JZ, Liu WJ, Smith SE, Smith FA, Zhu YG (2008) Do water regimes affect iron plaque formation and microbial communities in the rhizosphere of paddy rice? J Plant Nutr Soil Sci 171:193-199

Couture RM, Sekowska A, Fang G, Danchin A (2012) Linking selenium biogeochemistry to the sulfur-dependent biological detoxification of arsenic. Environ Microbiol 14:1612-1623

Ebbs S, Weinstein L (2001) Alteration of selenium transport and volatilization in barley (Hordeum vulgare) by arsenic. J Plant Physiol 158: $1231-1233$

Edmonds JS, Francesconi KA (1987) Transformations of arsenic in the marine environment. Experientia 43:553-557

Elrashidi MA, Adriano DC, Workman SM, Lindsay WL (1987) Chemical equilibria of selenium in soils: a theoretical development. Soil Sci 144:141-152

Feng RW, Wei CY, Tu SX, Sun X (2009) Interactive effects of selenium and arsenic on their uptake by Pteris vittata $\mathrm{L}$. under hydroponic conditions. Environ Exp Bot 65:363-368

Hartley-whitaker J, Ainsworth G, Meharg AA (2001) Copper and arsenate induced oxidative stress in Holcus lanatus L. clones with differential sensitivity. Plant Cell Environ 24:713-722

Hawkesford MJ, Zhao FJ (2007) Strategies for increasing the selenium content of wheat. J Cereal Sci 46:282-292

Hopper JL, Parker DR (1999) Plant availability of selenite and selenate as influenced by the competing ions phosphate and sulfate. Plant Soil 210:199-207

Islam RM, Meharg AA (2008) Inorganic arsenic in rice bran and its products are an order of magnitude higher than in bulk grain. Environ Sci Technol 42:7542-7546

Khattak RA, Page AL, Parker DR, Bakhtar D (1991) Accumulation and interactions of arsenic, selenium, molybdenum and phosphorus in alfalfa. J Environ Qual 20:165-168

Li HF, McGrath SP, Zhao FJ (2008) Selenium uptake, translocation and speciation in wheat supplied with selenate or selenite. New Phytol 178:92-102

Li G, Sun GX, Williams PN, Nunes L, Zhu YG (2011) Inorganic arsenic in Chinese food and its cancer risk. Environ Int 37:1219-1225

Lombi E, Scheckel KG, Pallon J, Carey AM, Zhu YG, Meharg AA (2009) Speciation and distribution of arsenic and localization of nutrients in rice grains. New Phytol 184:193-201

Ma JF, Yamaji N, Mitani N, Xu ZY, Su YH, McGrath SP, Zhao FJ (2008) Transporters of arsenite in rice and their role in arsenic accumulation in rice grain. Proc Natl Acad Sci U S A 105:9931-9935

Malik AJ, Goel S, Kaur N, Sharma S, Singh I, Nayyar H (2012) Selenium antagonises the toxic effects of arsenic on mungbean (Phaseolus aureus Roxb.) plants by restricting its uptake and enhancing the antioxidative and detoxification mechanisms. Environ Exp Bot 77: $242-248$

Meharg AA (2004) Arsenic in rice - understanding a new disaster for South-East Asia. Trends Plant Sci 9:415-417

Meharg AA, Hartley-Whitaker J (2002) Arsenic uptake and metabolism in arsenic resistant and nonresistant plant species. New Phytol 154:29-43

Meharg AA, Jardine L (2003) Arsenite transport into paddy rice (Oryza sa tiva) roots. New Phytol 157:39-44

Meharg AA, Macnair MR (1992) Suppression of the high affinity phosphate uptake system: a mechanism of arsenate tolerance in Holcus lanatus. J Exp Bot 43:519-524

Meng XY, Qin J, Wang LH, Duan GL, Sun GX, Wu HL, Chu CC, Ling HO, Rosen BP, Zhu YG (2011) Arsenic biotransformation and volatilization in transgenic rice. New Phytol 191:49-56

Onken BM, Hossner LR (1996) Determination of arsenic species in soil solution under flooded conditions. Soil Sci Soc Am J 60:1385-1392

Rahman MA, Hasegawa H, Rahman MM, Mazid Miah MA, Tasmin A (2008) Arsenic accumulation in rice (Oryza sativa L.): human exposure through food chain. Ecotoxicol Environ Safe 69:317-324

Srivastava M, Ma QL, Rathinasabapathi B, Srivastava P (2009) Effects of selenium on arsenic uptake in arsenic hyperaccumulator Pteris vittata $\mathrm{L}$. Bioresour Technol 100:1115-1121 
Sun GX, Liu X, Williams PN, Zhu YG, Deacon C (2010) Distribution and translocation of selenium from soil to grain and its speciation in paddy rice (Oryza sativa L.). Environ Sci Technol 44:6706-6711

Terry N, Zayed AM, de Souza MP, Tarun AS (2000) Selenium in higher plants. Annu Rev Plant Physiol Plant Mol 51:401-432

Williams PN, Islam S, Islam R, Jahiruddin M, Adomako E, Soliaman ARM, Rahman GKM, Lu Y, Deacon C, Zhu YG (2009a) Arsenic limits trace mineral nutrition (selenium, zinc, and nickel) in Bangladesh rice grain. Environ Sci Technol 43:8430-8436

Williams PN, Lombi E, Sun GX, Scheckel K, Zhu YG, Feng XB, Zhu JM, Carey AM, Adomako E, Lawgali Y (2009b) Selenium characterization in the global rice supply chain. Environ Sci Technol 43: 6024-6030
Wu ZC, Ren HY, McGrath SP, Wu P, Zhao FJ (2011) Investigating the contribution of the phosphate transport pathway to arsenic accumulation in rice. Plant Physiol 157:498-508

Zayed A, Lytle CM, Terry N (1998) Accumulation and volatilization of different chemical species of selenium by plants. Planta 206:284-292

Zhang LH, Shi WM, Wang XC (2006) Difference in selenium accumulation in shoots of two rice cultivars. Pedosphere 16:646-653

Zhao XQ, Mitani N, Yamaji N, Shen RF, Ma JF (2010) Involvement of silicon influx transporter OsNIP2;1 in selenite uptake in rice. Plant Physiol 153:1871-1877

Zhu YG, Pilon-Smits EAH, Zhao FJ, Williams PN, Meharg AA (2009) Selenium in higher plants: understanding mechanisms for biofortification and phytoremediation. Trends Plant Sci 14:436-442 